\title{
Sciendo
}

\section{THE RELATIONSHIP BETWEEN JOB SATISFACTION AND THE CONGRUENCE OF DESIRED AND PERCEIVED JOB ATTRIBUTES: AN EXPLORATORY STUDY OF IT PROFESSIONALS}

\author{
Loredana MIHALCA* \\ Babeș-Bolyai University, Romania. Department of Economics \\ and Business Administration in German Language
}

\begin{abstract}
The main purpose of this study was to investigate whether employee job satisfaction is associated with the congruence between desired and perceived job attributes. The desired and perceived levels of 30 job attributes were measured on employees from a large Information Technology (IT) company based in Romania. Results indicate that employees who experience congruence between desired and perceived job attributes have higher levels of overall job satisfaction, confirming the assumptions of the value congruence theory. In addition, the results of this study show that employee job satisfaction is associated with both intrinsic and extrinsic factors i.e., job attributes. This indicates that extrinsic factors can also be a source of job satisfaction, the same as intrinsic factors, which is contrary to what Herzberg's motivation-hygiene theory assumes.
\end{abstract}

Keywords: job attributes; job satisfaction; the value congruence theory; IT professionals; newly-hired;

JEL classification: J24, M15.

\section{Introduction}

Information technology (IT) is currently one of the fastest-growing sectors, and thus there is a need for a continuous supply of high-quality IT professionals (Trauth et al., 2009). In addition, the retention of qualified employees represents a critical aspect for organizations given the high turnover rates of IT professionals (see Joseph et al., 2007, for a meta-analysis), especially during the early years of their employment (see Mihalca et al., in press).

\footnotetext{
Corresponding author. Address: Faculty of Economics and Business Administration, Babeș-Bolyai University, Cluj-Napoca, Romania, 400591 Th. Mihali Street 58-60, Tel. +40 264 418655, Fax. +40 264 412570, loredana.mihalca@econ.ubbcluj.ro
} 
Research on employee turnover has shown that job satisfaction is negatively related to intentions to quit (i.e., turnover intentions), which in turn are positively associated with actual turnover (Boswell et al., 2005; Chen et al., 2011; for meta-analyses, see Griffeth et al., 2000; Tett and Meyer, 1993). Similarly, studies on turnover among IT professionals have indicated that job satisfaction is a key factor for turnover of these professionals (e.g., Chen, 2008; Niederman and Sumner, 2004). Therefore, in order to manage IT professionals' turnover, organizations need to identify the factors that positively influence their job satisfaction.

There are numerous factors that may influence employee job satisfaction (Chen, 2008). Among these factors, situational factors including attributes that are specific to a job (e.g., type of work, salary, opportunities for advancement) and attributes that are more widely reflective of the organizations (e.g., company size, reputation, and work environment) have been found to be important predictors of job satisfaction (e.g., Boswell et al., 2009; Hackman and Oldham, 1975). In addition, it has been found that employee job satisfaction is higher when there is a congruence between what employees want from their jobs (i.e., desired job attributes) and their perception of what they receive (i.e., perceived job attributes; e.g., Humphrys, 1981; O'Brien and Dowling, 1980; Warr and Inceoglu, 2012). The results of the existing studies on the relationship between employee job satisfaction and the congruence of desired and perceived job attributes are inconclusive. While some studies supported the hypothesis that job satisfaction is higher when the job attributes preferred by employees match the job attributes emphasized in their organizations (i.e., the value congruence hypothesis; e.g., Barrett, 1978), other studies did not support this hypothesis (e.g., Baker and Hansen, 1975). Furthermore, in the majority of these studies a limited number of desired and perceived job attributes (e.g., five job attributes; Humphrys, 1981; O'Brien and Dowling, 1980; for an exception, see Warr and Inceoglu, 2012) has been investigated. In order to improve the understanding of what job attributes influence employee job satisfaction and whether the congruence of desired and perceived job attributes relates with job satisfaction, a broader array of job attributes should be captured (cf. Chen et al., 2011). In the current study, a comprehensive list of job attributes, including items about flexible working hours, work-life balance, autonomy, in addition to the items commonly used in early studies (e.g., Harris and Fink, 1987; Turban et al. 1998; see Mihalca et al., in press) was used.

The main aim of this study was to determine whether IT professionals' job satisfaction is related to the congruence between their preferred job attributes and the job attributes that are emphasized in their organization. The current study also aimed at investigating (1) which job attributes are the most important for IT professionals when making job choice decisions and which job attributes are the most experienced in their organization, and (2) which of the desired and perceived job attributes are associated with job satisfaction.

\section{Literature review}

\subsection{Job and organizational attributes}

Job and organizational attributes refer to specific qualities or outcomes of the job or the organization, which can be used to enhance the attractiveness of a job for both prospective and current employees (Konrad et al., 2000). As mentioned 
before, the attributes specific to a job include salary, type of work, opportunities for advancement, and the attributes that are more widely reflective of the organization include company size, location, reputation, work environment (Chapman et al., 2005). Throughout this study, I use the term "job attributes" for the sake of simplicity.

Behling et al. (1968) proposed three theories that explain the influence of job attributes on organizational attractiveness and job choice decisions: the objective factor theory, the subjective factor theory, and the critical contact theory. The objective and subjective factor theories are of particular relevance for this study, because its aim to understand how IT employees use information about job attributes when making job choice decisions. The objective factor theory assumes that job choice decisions are based on the evaluations that job applicants or prospective employees make about the advantages and disadvantages of tangible job attributes such as salary, fringe benefits, type of work (see Harold and Ployhart, 2008). These evaluations subsequently inform job applicants about the desirability of a job and influence their job choice behavior. According to the subjective factor theory, applicants assess the organization's environment and make judgments about how well they fit with the organization in regard to their desires, needs, values, and traits (Behling et al., 1968). Thus, applicants' job choices are influenced by their perceptions that the organization's environment fits their desires, needs, values, and traits (Harold and Ployhart, 2008).

Another theory referring to individuals' perceptions of subjective fit is Schneider's (1987) attraction-selection-attrition theory, according to which individuals are attracted to jobs and/or organizations which have attributes that match their own characteristics (i.e., attraction component; see Erhart and Ziegert, 2005). Although initially individuals may be attracted to or selected by an organization, they are likely to leave the organization if a poor fit is perceived later on (i.e., attrition component; see Acikgoz, 2019). Therefore, organizations that want to attract and retain the best employees have not only to know what job attributes are most or least attractive for them, but be aware of the changing needs of employees and responding to these needs accordingly (cf. Harold and Ployhart, 2008).

Numerous studies have investigated individuals' job attribute preferences and their importance for job choice decisions and organizational attractiveness (e.g., Boswell et al., 2003; Harris and Fink, 1987; Jurgensen 1978; Posner 1981; Turban et al., 1998; for meta-analyses, see Chapman et al., 2005; Uggerslev et al., 2012). Early studies on job attribute preferences were mostly focused on exploring which single attributes were rated as important in evaluating jobs, and whether these attributes influence job choices (e.g., Jurgensen 1978; Posner 1981). For example, in his study Jurgensen (1978) asked all job applicants of a utility company $(N=57,000)$ to rank the importance of 10 attributes in terms of what makes a job good or bad, and found that job security, advancement opportunity, type of work, and company characteristics were the most important attributes in their job choice decisions. Posner (1981) asked 148 college students to rate the importance of $18 \mathrm{job}$ attributes and found that the most preferred job attributes were all pertaining to characteristics of job itself (e.g., challenging and interesting work, opportunity to use abilities, opportunity to learn).

These early studies were followed by studies that focused on the relationship between job attributes and different aspects of job choice such as recruiter behaviors (Harris and Fink 1987; Turban et al. 1998) and recruiting practices (Powell, 1984, 
1991). In these studies, the underlying constructs of the job attributes measures were used to explore the relationship between applicant perceptions and job choice decisions. For example, in Powell's $(1984,1991)$ studies three underlying constructs, that is, job itself, compensation/security, and company/work environment were identified job attributes items such as challenging and interesting work, variety of activities, opportunity for rapid advancement loaded on job itself factor, items such as salary and fringe benefits loaded on compensation/security factor, and items such as training programs, location, and reputation of company loaded on company/work environment factor. In Powell's (1984) study, job attributes but not recruiting practices have been found to influence the probability of a job acceptance.

In these early studies, job attributes scales did not include items about the availability of flexible work schedules or work-life balance (Carless and Imber, 2007), which have become increasingly important in recent years for job applicants (Twenge and Kasser, 2013). For example, there is some evidence that applicants are more attracted to firms with flexible work schedules and a high level of work-life balance (e.g., Casper and Buffardi 2004). Work hours and work-life balance are also frequently mentioned as important factors in recruiting and retaining IT professionals, because these professionals have been found to work longer hours and have less work-life balance than their non-IT counterparts (Kuhn and Joshi 2009; see also Mihalca et al., in press). To address this issue, was used a comprehensive list of job attributes was used, including items about flexible working hours and work-life balance in addition to the items commonly used in early studies (e.g., Harris and Fink 1987; Turban et al. 1998).

\subsection{Job satisfaction and factors that influence job satisfaction}

Job satisfaction, defined as "the pleasurable emotional state resulting from the appraisal of one's job as achieving or facilitating the achievement of one's job values" (Locke, 1969; p. 316) represents one of the most frequently studied variables in organizational research (Dormann and Zapf, 2001). It has been associated with several important employee outcomes such as organizational commitment, turnover, absenteeism, organizational citizenship behaviors, and work performance (e.g., Cohrs et al., 2006; Keller and Semmer, 2013).

According to situational theories (e.g., Herzberg's motivation-hygiene theory, 1966; the Job Characteristics Model by Hackman and Oldham, 1976), job satisfaction is determined by characteristics of the job and work environment (see Cohrs et al., 2006). Herzberg (1966) developed a two-factor theory which argues that job satisfaction and dissatisfaction are two separate, and sometimes, unrelated constructs that are determined by different factors. Whereas job satisfaction is determined by intrinsic factors or motivators such as work itself, responsibility, recognition, and advancement, dissatisfaction is caused by extrinsic or hygiene factors such as salary, benefits, job security, supervision, and interpersonal relations (Judge et al., 2002). The most important difference between motivators and hygiene factors is that motivators contribute to personal growth, while hygiene factors contribute to the avoidance of physical and psychological discomfort (Sachau, 2007). Although this theory has an intuitive appeal, there is little empirical support for its assumptions (Judge et al., 2002). In addition, there is consistent empirical evidence 
that both intrinsic and extrinsic factors can be sources of job satisfaction (e.g., Taylor and Westover, 2011), which is contrary to what Herzberg (1966) claimed.

Another situational theory of job satisfaction, which unlike Herzberg's (1966) theory has received more empirical support is the Job Characteristics Model developed by Hackman and Oldham (1976). According to this model, enriched jobs or jobs that have five core characteristics, that is, skill variety (the degree to which job requires a variety of different skills), task identity (the degree to which job requires doing a whole and identifiable piece of work), task significance (the degree to which job has an impact on the lives of others), autonomy (the degree to which job provides substantial freedom or control over work), and feedback (the degree to which work itself provides employees with performance information) are more satisfying and motivating. These work characteristics are assumed to increase job satisfaction through their influence on three critical psychological states, that is, experienced meaningfulness (the degree to which employees feel that the job is valuable and important), experienced responsibility (the degree to which employees feel responsible for work results), and knowledge of results (the degree to which employees are aware of their effectiveness at work; see Humphrey et al., 2007).

Research has provided evidence for the proposed relationship between the core job characteristics and several attitudinal and behavioral outcomes (e.g., job satisfaction, internal work motivation, job performance; see Fried and Ferris, 1987; Humphrey et al., 2007; Loher et al., 1985, for meta-analyses). Furthermore, research has revealed that of the many aspects of work situation that are associated with job satisfaction (e.g., salary, promotion opportunities, coworkers, supervision), the nature of work has the highest correlation with overall job satisfaction (see Judge et al., 2002).

\subsection{Congruence between desired and perceived job attributes and its relationship with job satisfaction}

The value congruence theory of job satisfaction (Locke, 1969) states that employees' job satisfaction is highest when their desired job attributes are congruent with what the job or the organization perceived as offering (see Humphrys, 1981). Several studies have investigated the relationship between the congruence of desired and perceived job attributes and job satisfaction (e.g., O'Brien and Dowling, 1980, Warr and Inceoglu, 2012), but the results are inconclusive. As already mentioned, some studies have reported a correlation between the congruence of desired and perceived job attributes and employee job satisfaction (e.g., Barrett, 1978; Humphrys, 1981; O'Brien and Dowling, 1980), however this correlation was lower than the correlation between perceived job attributes and job satisfaction. For example, in the study by O'Brien and Dowling (1980), the value congruence hypothesis was supported only for two job attributes (i.e., skill-utilization and variety), but not for the other three job attributes measured (i.e., influence, pressure, and social interaction). Moreover, this study indicated that perceived job attributes alone represent a much stronger predictor of job satisfaction than the congruence between desired and perceived job attributes.

In his study, Humphrys (1981) found only little support for the hypothesis that the congruence between desired and perceived job attributes is a better predictor of job satisfaction when the importance of job attributes is weighted. $\mathrm{He}$ found that unweighted discrepancy scores (i.e., difference scores used as a measure 
of value congruence) also significantly predicted job satisfaction. In addition, the results indicated that the best predictor of job satisfaction is the perceived level of job attributes, not the congruence between desired and perceived job attributes, which supports the findings by O'Brien and Dowling (1980).

In a more recent study, Warr and Inceoglu (2012) tested the hypothesis that poor person-job fit causes lower levels of job satisfaction, using a sample of 840 employees from several countries (e.g., United Kingdom, Australia). Person-job fit, that is, the fit between wanted and actual levels of 33 job attributes was examined using both algebraic and absolute scoring. According to the authors, algebraic scoring (i.e., wanted-minus-actual levels of job attributes) emphasizes poor fit in a positive direction, indicating that employees want a specific job attribute more than they perceive their organization offers. On the contrary, absolute scoring emphasizes "wanting less in addition merely to wanting more" (p. 133). The results indicated that poor fit between wanted and actual levels of job attributes is negatively correlated to job satisfaction, especially in terms of absolute incongruence.

Based on prior research, I expect that employees who experience a match or congruence between the desired and the perceived job attributes will be more satisfied with their job. Thus, I postulate the following:

Hypothesis 1: The congruence between desired and perceived job attributes will positively correlate with job satisfaction of IT professionals.

\section{Methodology}

\section{Sample description}

The sample used in this study comprises 23 employees from a large IT company based in Romania. The mean age of respondents was 26.30 years ( $S D=$ 4.02) and their median job tenure was 8.00 months (range: 1-72 months). Thirteen of the respondents $(56 \%)$ were males and ten $(44 \%)$ of them were females. Respondents held a variety of job positions: $22 \%$ were IT developers, $22 \%$ were human resources (HR) consultants, $22 \%$ were middle managers, $17 \%$ were testers, $13 \%$ were quality assurance specialists, and one respondent was an intern. The other demographic data (e.g., level of education, type of contract) collected in this study is presented in Table 1 (see also Mihalca et al., in press).

Table 1: Sociodemographic characteristics of the sample $(N=23)$

\begin{tabular}{llcc}
\hline Variables & & Frequency & Percentage \\
\hline \multirow{2}{*}{ Gender } & Female & 10 & $44 \%$ \\
& Male & 13 & $56 \%$ \\
Marital status & Married/in a relation & 11 & $48 \%$ \\
& Single & 11 & $48 \%$ \\
Children & Yes & 2 & $9 \%$ \\
Level of education & No & 21 & $91 \%$ \\
& Bachelor degree & 14 & $61 \%$
\end{tabular}




\begin{tabular}{llcc}
\hline Variables & & Frequency & Percentage \\
\hline \multirow{4}{*}{ Major } & Master degree & 9 & $39 \%$ \\
& Computer science & 9 & $39 \%$ \\
& Economics/Managem. & 8 & $35 \%$ \\
& Humanities & 5 & $22 \%$ \\
\multirow{3}{*}{ Type of contract } & Others & 1 & $4 \%$ \\
& Full-time & 12 & $54 \%$ \\
& Part-time & 5 & $23 \%$ \\
Job satisfaction & Registered sole trader & 3 & $14 \%$ \\
& Temporary & 2 & $9 \%$ \\
& Somehow satisfied & 7 & $30 \%$ \\
\hline
\end{tabular}

Note. Managem. $=$ Management. One participant $(4 \%)$ did not mention her/his marital status.

Measures

Desired job attributes. Employees' desired levels of various job attributes were measured with a 31-item questionnaire based on the most commonly used items in the recruitment literature (e.g., Harris and Fink, 1978; Turban et al., 1995; Uggerslev et al., 2012). The participants were requested to rate the importance of 31 job and organizational attributes when making job choice decisions, on a 7-point Likert scale, ranging from 1 (not at all important) to 7 (extremely important). The full list of desired job attributes can be seen in Figure 1.

Perceived job attributes. The perceived job attributes items were similar to those used to assess preferred or desired job attributes, but this time participants were asked to describe in which degree the company presents these job attributes. Participants rated their responses on a 7-point Likert scale from $1=$ absolutely false to $7=$ absolutely true. The full list of perceived job attributes can be seen in Figure 2. It should be noted that only 30 perceived job attributes were presented in the current study, as many participants did not rate the perceived level of the job attribute "location".

Job satisfaction. The overall job satisfaction of the employees was assessed using a single-item on a 4-point scale, ranging from not at all satisfied to very satisfied. The item used to measure job satisfaction was "How satisfied would you say you are with your job?". Single-item measures of job satisfaction have been found to be reliable and more robust than multiple-item scales (Wanous et al., 1997).

\section{Procedure}

Employees who were newly-hired or during the early years of their employment were invited to take part in the study. An e-mail invitation describing the purpose of the study was sent to the HR representative of the IT company, who then sent it to targeted employees. Employees were promised confidentiality, and oral consent was obtained from those who accepted to participate in the study. After completing a survey containing questions about preferred job attributes, job 
satisfaction, and demographic factors (e.g., age, gender), participants rated the degree to which the listed job attributes are experienced in their organization (i.e., perceived job attributes) and then described in details during a semi-structured interview how these attributes are experienced in their jobs. All interviews were audiotaped, transcribed, and analyzed using thematic analysis, however these results will be reported elsewhere.

\section{Results}

\section{Descriptive statistics}

Means and standard deviations were computed for both desired and perceived job attributes (see Table 2).

\section{Table 2: Means (M) and standard deviations (SD) of the desired and perceived job attributes}

\begin{tabular}{|c|c|c|c|c|}
\hline \multirow[t]{2}{*}{ Job attributes items } & \multicolumn{2}{|c|}{ Desired } & \multicolumn{2}{|c|}{ Perceived } \\
\hline & $M$ & $S D$ & $M$ & $S D$ \\
\hline Good training opportunity & 6.17 & 1.03 & 6.35 & .78 \\
\hline Opp. for long-term career & 6.52 & .67 & 5.83 & 1.34 \\
\hline Variety in daily work & 6.39 & .89 & 5.96 & 1.07 \\
\hline Dynamic approach & 5.87 & 1.18 & 6.26 & .75 \\
\hline Friendly and informal culture & 6.00 & 1.17 & 6.48 & .73 \\
\hline $\begin{array}{l}\text { Opp. for career develop. within } \\
\text { organization }\end{array}$ & 6.48 & 0.79 & 6.04 & .77 \\
\hline Opp. for rapid career advancement & 5.61 & 1.37 & 5.14 & 1.19 \\
\hline Freedom to work on own initiative & 5.91 & 1.16 & 5.91 & 1.02 \\
\hline Opp. to do creative work & 6.17 & .89 & 5.77 & 1.07 \\
\hline Relaxed work atmosphere & 6.26 & .86 & 6.65 & .57 \\
\hline Rewards based on performance & 6.30 & 0.93 & 5.64 & 1.36 \\
\hline Opp. to travel & 4.65 & 1.30 & 5.82 & 1.30 \\
\hline Good salary & 6.35 & 0.78 & 5.65 & 1.56 \\
\hline Good fringe benefits & 6.09 & 1.08 & 5.91 & 1.08 \\
\hline Reputation of the company & 4.83 & 1.30 & 6.26 & 1.18 \\
\hline Size of the company & 3.96 & 1.49 & 6.09 & .79 \\
\hline Flexible working hours & 6.17 & 0.98 & 6.48 & .79 \\
\hline Relatively stress-free env. & 4.91 & 1.83 & 5.30 & 1.18 \\
\hline Job security & 6.00 & 1.28 & 6.26 & 1.14 \\
\hline Opp. to use individual abilities & 6.35 & 0.88 & 6.17 & .89 \\
\hline Challenging and interesting work & 6.52 & 0.73 & 6.36 & .90 \\
\hline Location of the company & 4.22 & 1.74 & & \\
\hline Opp. to learn and acquire new skills & 6.30 & 0.93 & 6.35 & .88 \\
\hline Support for initiative taking & 6.00 & 1.00 & 6.17 & .89 \\
\hline Provision of performance feedback & 6.22 & 0.95 & 6.00 & 1.38 \\
\hline Opp. for teamwork & 5.30 & 1.22 & 6.74 & .54 \\
\hline $\begin{array}{l}\text { Autonomy in duration/way of doing } \\
\text { job }\end{array}$ & 5.04 & 1.19 & 5.53 & 1.44 \\
\hline Work-life balance & 6.56 & 0.66 & 4.86 & 1.71 \\
\hline Frequent salary increases & 6.00 & 1.13 & 6.00 & 1.45 \\
\hline Good relations with supervisors & 6.30 & 1.22 & 6.70 & .63 \\
\hline Corporate social responsibility & 4.56 & 1.73 & 6.65 & .78 \\
\hline
\end{tabular}

Note. Opp. = opportunity; develop. = development; env. = environment. 
The mean importance ratings for the 31 desired job attributes are presented in Figure 1. Analyzing Figure 1, it can be seen that work-life balance was the most important job attribute for the employees, with a mean of 6.56. Challenging and interesting work as well as opportunities for long-term career development $(M=6.52)$ were among the top rated job attributes when making job choice decisions. Opportunities for career development within the organization $(M=6.48)$ and variety in daily work $(M=6.39)$ were next, indicating employees' desire for professional growth to take on high-level positions. Good salary $(M=6.35)$ was rated sixth behind the job attributes related to career development and type of work (e.g., challenging and interesting work). The least important job attributes were corporate social responsibility $(M=4.56)$, location ( $M=4.22)$, and size of the company $(M=3.96)$.

Fig. 1: Mean ratings of desired job attributes

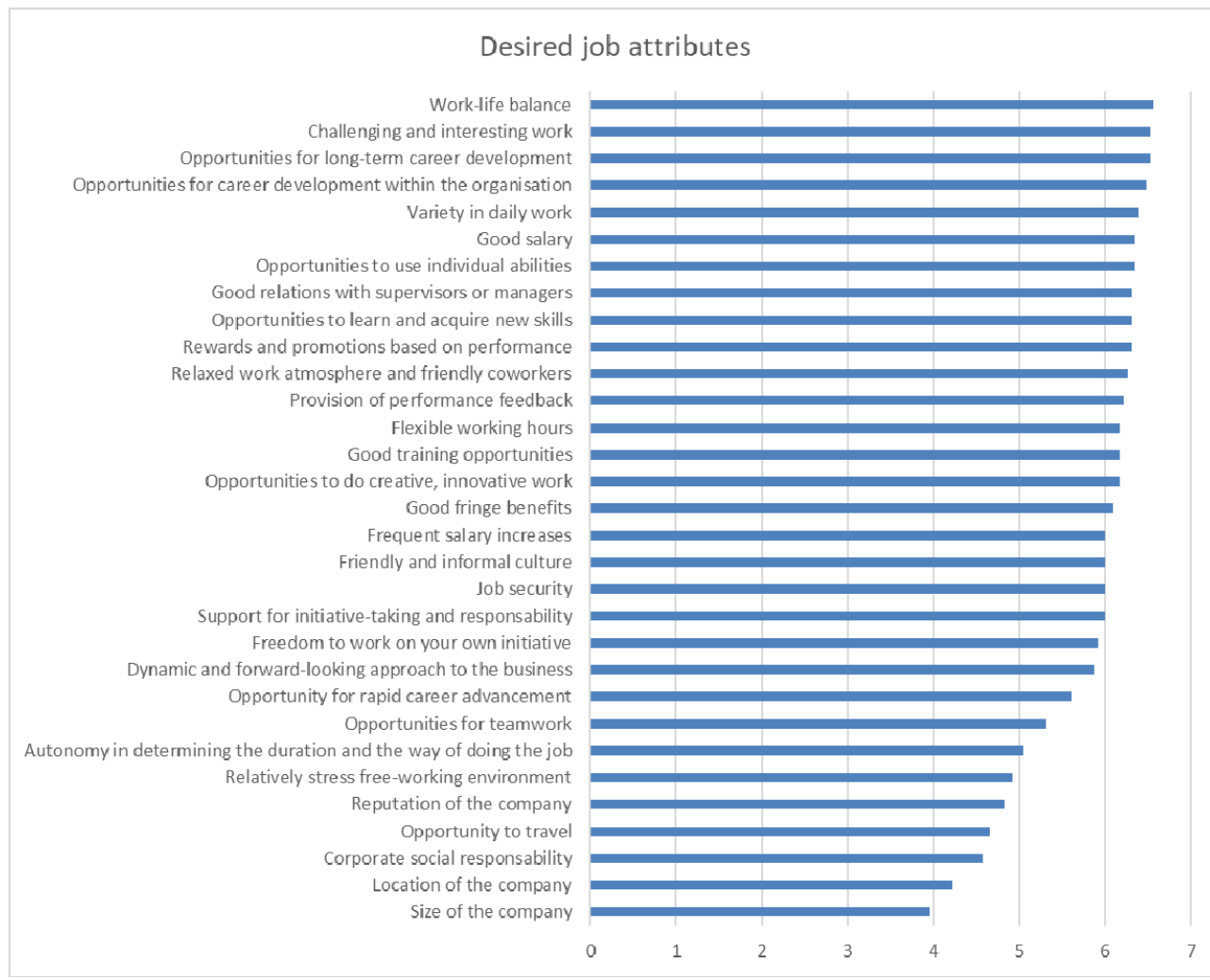

Figure 2 presents the means of perceived job attributes. As can be seen in Figure 2, employees rated opportunities for teamwork $(M=6.74)$ as the most experienced job attribute in their company. Good relations with supervisors or managers $(M=6.70)$, corporate social responsibility, and relaxed atmosphere and friendly coworkers $(M=6.65)$ were among the top rated perceived job attributes. Flexible working hours and friendly and informal culture $(M=6.48)$ were rated fifth and sixth highest. The perceived job attributes rated lowest by the employees 
were: relatively stress free-working environment $(M=5.30)$, opportunity for rapid career advancement $(M=5.14)$, and work-life balance $(M=4.86)$.

Fig. 2: Mean ratings of perceived job attributes

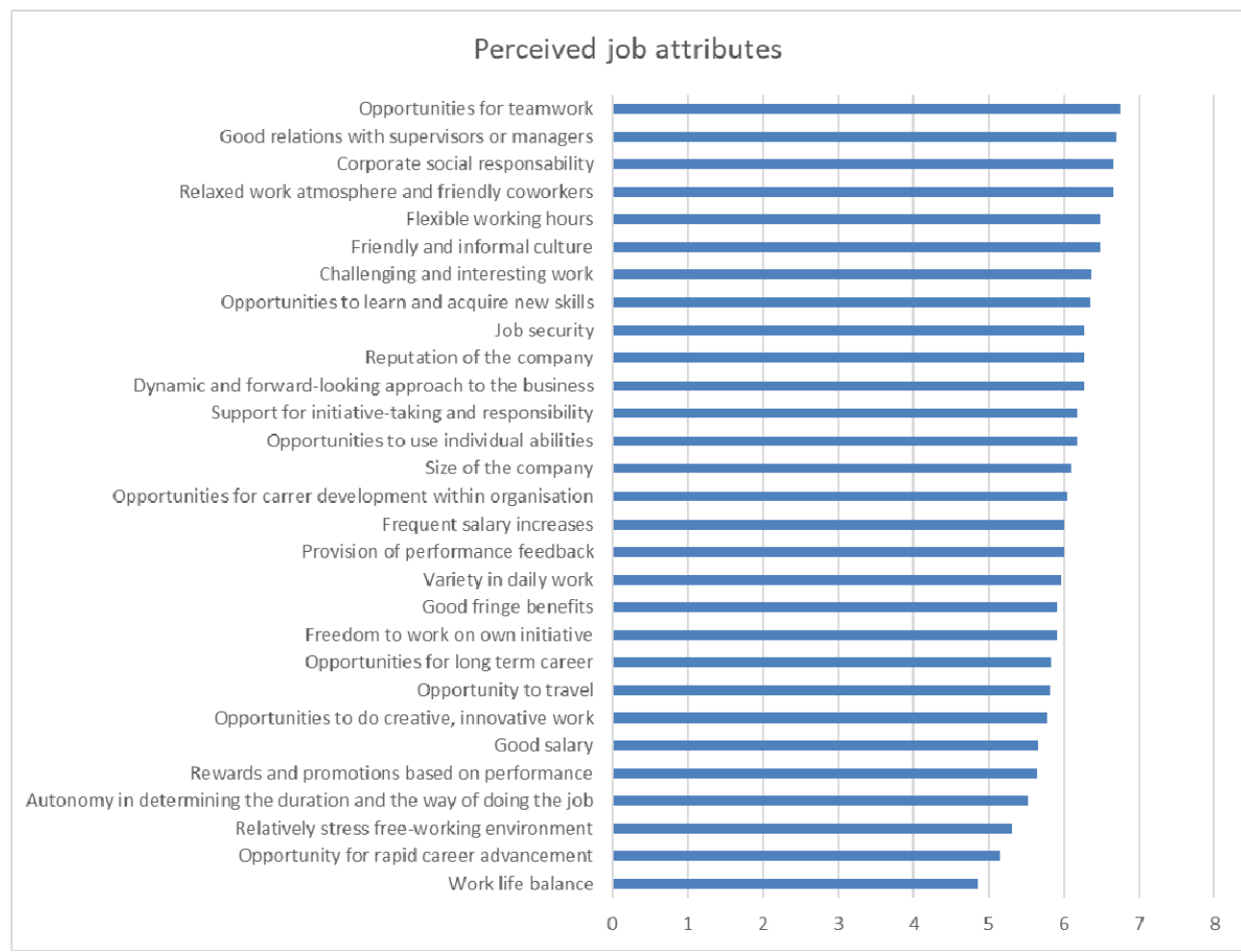

Correlations between desired and perceived job attributes and job satisfaction

Correlation analyses were conducted to examine the relationship between desired job attributes and job satisfaction as well as between perceived job attributes and job satisfaction. Kendall's tau correlations were computed between-subjects because of the non-normal distribution of the data and the small sample size (see Tables A1 and A2 in Annex 1). As can be seen in Table A1, job satisfaction was positively and significantly correlated with 12 out of 31 desired job attributes. The strongest positive correlations were obtained between job satisfaction and the following desired job attributes: relaxed atmosphere and friendly coworkers $(\tau=.64$, $p=.002)$, job security $(\tau=.64, p=.001)$, provision of performance feedback $(\tau=.57$, $p=.005)$, and reputation of the company $(\mathrm{\tau}=.55, p=.005)$. It is noteworthy that none of the desired job attributes strongly related to job satisfaction are among the top ten-rated job attributes, and only one of all job attributes (i.e., opportunities to use individual abilities), which correlated moderately with job satisfaction is among the top ten-rated job attributes. 
Regarding the correlations between job satisfaction and perceived job attributes, 16 out of 30 perceived job attributes were positively and statistically correlated with overall job satisfaction (see Table A2). It is noteworthy that the majority of the perceived job attributes that correlated strongly with job satisfaction are intrinsic attributes such as challenging and interesting work $(\mathrm{T}=.78, p=.000)$, autonomy in determining the duration and the way of doing the job $(\tau=.54, p=.005)$, provision of performance feedback ( $\mathrm{T}=.53, p=.005)$, opportunities for career development within organization ( $\mathrm{T}=.51, p=.011$ ), support for initiative taking and responsibility $(\mathrm{T}=.51, p=.011)$, and are not placed in the top-ten experienced job attributes (except for challenging and interesting work). However, job satisfaction was also correlated, strongly and moderately, with extrinsic job attributes such as opportunity to travel $(\mathrm{T}=.66, p=.001)$, frequent salary increases $(\mathrm{T}=.48, p=.014)$, and good fringe benefits $(\tau=.39, p=.046)$.

Correlation between congruence of desired and perceived job attributes and job satisfaction

To test the hypothesis that congruence between desired and perceived job attributes correlates with job satisfaction, I first computed the within-person gamma correlations as a measure of this congruence. The within-person gammas were calculated by correlating the ranking of desired job attributes with the ranking of perceived job attributes for each individual participant. Gamma provides a measure of the congruence between desired and perceived job attributes, which is independent of the absolute values of the ratings of these job attributes categories. This means that participants who rated high the job attributes can have the same gamma as participants who rated low these job attributes. As in the case of any correlation coefficients, gamma values range between -1.00 and +1.00 . A value of one indicates a perfect congruence, that is, all desired job attributes are ranked in the same order as the perceived job attributes, whereas a value of zero indicates no congruence. A value of minus one indicates that the desired job attributes are not experienced by employees in their company or that the perceived job attributes are not important for participants when making job choice decisions.

Next, to test whether gamma was related to job satisfaction, I computed a Kendall's tau correlation between gamma and the score of overall job satisfaction. The correlation was significant $(\tau=.34, p=.031$, one-tailed), indicating that the more participants experience a congruence between the desired and perceived job attributes, the more they are satisfied with their job, and the more they experience a discrepancy (i.e., no congruence), the less they are satisfied with their job.

\section{Conclusion}

The main aim of this study was to investigate whether IT professionals' job satisfaction is associated with the congruence between what they want from a job and what they get from the job or organization. Results indicate that the congruence between desired and perceived job attributes relates positively to job satisfaction, which is consistent with previous studies that found support for the assumptions of the value congruence theory (e.g., Humphrys, 1981; O'Brien and Dowling, 1980). 
One major implication of these results is that organizations should pay attention to the job attributes that employees are looking for and should narrow the discrepancy between desired and perceived job attributes in order to enhance the levels of job satisfaction among their employees. The most preferred job attributes for the employee sample included in this study were intrinsic factors referring to type of work (e.g., challenging and interesting work, variety in daily work), career development (e.g., opportunities for long-term career development), and supportive work environment (e.g., work-life balance). This suggests that intrinsic factors are more important for IT professionals when making job choice decisions than extrinsic factors such as salary (rated as the sixth most important job attribute), fringe benefits, and job security. These results are partially consistent with prior research (e.g., Kuhn and Joshi, 2009; Trauth et al., 2009). For example, in their study Kuhn and Joshi (2009) investigated gender differences in job attribute preferences of prospective IT professionals and found that work-life balance, social interaction, and salary were the most preferred job attributes by both men and women.

It is noteworthy that the most preferred job attributes are not among the top rated perceived job attributes, except for challenging and interesting work that was rated as the seventh most experienced job attribute. The largest discrepancies between desired and perceived job attributes occurred in the ratings of size of the company, corporate social responsibility, work-life balance, opportunity to travel, good salary (the difference is over 1.00 point). Except for work-life balance, for all the other mentioned job attributes, the identified discrepancies indicate that IT employees experienced these specific job attributes more than desired (i.e., the perceived level is above the desired level). In the case of work-life balance and other three job attributes for which the differences were over .50 points (i.e., good salary, opportunities for long-term career, rewards and promotions based on performance), employees wanted greater amounts of those job attributes than are perceived to be present in the organization.

Another interesting finding is that only a very few top rated desired and perceived job attributes are related to job satisfaction. In particular, job satisfaction correlated with opportunities to use individual abilities, which was rated as the seventh most important job attribute, as well as with challenging and interesting work, and opportunities to learn and acquire new skills that were rated as the seventh and the eighth most experienced job attributes in the organization. One possible explanation for this finding is that employees are not aware of which job attributes are the most important predictors of their job satisfaction, or they are not able to determine the hierarchy of their job values (Humphrys, 1981). To increase employee awareness of the desired job attributes that are responsible for job satisfaction, it may be useful for organizations to increase the perceived level of the intrinsic job attributes that are associated with job satisfaction, as it has been found that this may result in an increase of the desired level of those specific job attributes (see Humphrys, 1981). In this study, the majority of the perceived job attributes related to job satisfaction were intrinsic factors referring to the nature of work, advancement, recognition, and responsibility.

The results of this study also suggest that employee job satisfaction is associated with both intrinsic and extrinsic factors, which contradicts the assumptions of Herzberg's motivation-hygiene theory (1966). However, these results are in 
accordance with the findings of studies, which have revealed that both intrinsic and extrinsic factors can be sources of job satisfaction (e.g., Mihalca et al., in press; Taylor and Westover, 2011).

Implications of the results for recruitment and retention of IT professionals should be considered with caution in view of the limitations of this study. First, this study focuses on self-reported job attributes, and thus is subject to enhanced social desirability response biases. Future studies should use other methods to capture the desired and perceived job attributes of IT sector employees (e.g., policy capturing; see Mihalca et al., in press), or include objective measures of job attributes (O'Brien and Dowling, 1980) to diminish the biases associated with self-reported data. Second, the study used a very small, non-representative sample of employees, which was obtained from a single IT company. It would be useful to replicate the results using a larger and more diverse employee sample, from multiple organizations in the same industry. The use of a larger sample will also allow to test the value congruence hypothesis using regression analyses and to determine whether job satisfaction is more strongly related to the congruence between desired and perceived job attributes than to job attributes alone (e.g., O'Brien and Dowling, 1980). Third, this is a cross-sectional study, which cannot provide information about cause-and-effect relationships (e.g., relationship between job attributes and job satisfaction) or track the changes in job attribute preferences over time. As the perceived importance of job attributes have been found to change over time as a result of employee work experience (see Mihalca et al., in press), future research should employ longitudinal designs to determine to what extent the desired and perceived job attributes, and their relationship with job satisfaction might change over time.

Future research avenues should also focus on investigating whether the value congruence theory is more applicable to employees with certain individual characteristics such as ability, personality (e.g., high self-efficacy, high need achievement; cf. Humphrys, 1981).

To conclude, the findings reported in this study pinpoint the need to find an appropriate balance between desired and perceived job attributes as a useful approach to increase employee job satisfaction.

\section{Acknowledgments}

This research was supported by UBB-NTT DATA Advanced Fellowship implemented through the Institute for Advanced Studies in Science and Technology of the Babeș-Bolyai University (STAR-UBB Institute), Romania. I thank Christoph Mengelkamp for helping me with the statistical analyses, and for his useful comments on the Results section. 


\section{Annex 1}

Table A1: Correlations between desired job attributes and job satisfaction

\begin{tabular}{|c|c|c|c|c|c|c|c|c|c|c|c|c|c|}
\hline & 1. & 2. & 3. & 4. & 5. & 6. & 7. & 8. & 9. & 10. & 11. & 12. & 13. \\
\hline $\begin{array}{l}\text { 1. Dynamic } \\
\text { approach }\end{array}$ & - & & & & & & & & & & & & \\
\hline $\begin{array}{l}\text { 2. Relaxed work } \\
\text { atmosphere }\end{array}$ & $.55^{\star *}$ & - & & & & & & & & & & & \\
\hline $\begin{array}{l}\text { 3. Good fringe } \\
\text { benefits }\end{array}$ & $.38^{*}$ & $.42^{*}$ & - & & & & & & & & & & \\
\hline $\begin{array}{l}\text { 4. Reputation of } \\
\text { the company }\end{array}$ & .24 & $.43^{*}$ & $.45^{\star}$ & - & & & & & & & & & \\
\hline $\begin{array}{l}\text { 5. Size of the } \\
\text { company }\end{array}$ & $.37^{*}$ & $.65^{\star *}$ & .29 & $.66^{\star *}$ & - & & & & & & & & \\
\hline $\begin{array}{l}\text { 6. Relatively } \\
\text { stress-free } \\
\text { environment }\end{array}$ & $.39^{*}$ & $.56^{\star *}$ & $.48^{* *}$ & $.37^{*}$ & $.47^{* *}$ & - & & & & & & & \\
\hline 7. Job security & $.46^{*}$ & $.64^{* *}$ & $.54^{* *}$ & $.62^{* *}$ & $.39^{*}$ & $.42^{*}$ & - & & & & & & \\
\hline $\begin{array}{l}\text { 8. Opp. to use } \\
\text { individual } \\
\text { abilities }\end{array}$ & .28 & .30 & $.44^{*}$ & .30 & .22 & $.37^{*}$ & .26 & - & & & & & \\
\hline $\begin{array}{l}\text { 9. Support for } \\
\text { initiative taking }\end{array}$ & $.45^{\star}$ & $.49^{*}$ & $.60^{* *}$ & $.40^{*}$ & .28 & .34 & $.51^{*}$ & .36 & - & & & & \\
\hline $\begin{array}{l}\text { 10. Provision of } \\
\text { performance } \\
\text { feedback }\end{array}$ & .28 & $.39^{*}$ & $.68^{* *}$ & $.48^{* *}$ & .25 & $.36^{*}$ & $.60^{* *}$ & $.49^{*}$ & $.68^{* *}$ & - & & & \\
\hline $\begin{array}{l}\text { 11. Autonomy in } \\
\text { duration/way of } \\
\text { doing job }\end{array}$ & .45 & $.55^{\star *}$ & .32 & $.54^{\star *}$ & $.55^{\star *}$ & $.36^{*}$ & $.40^{*}$ & .35 & .30 & .30 & - & & \\
\hline $\begin{array}{l}12 \text { Corporate } \\
\text { social resp. }\end{array}$ & .18 & $.40^{*}$ & $.50^{\star *}$ & $.62^{\star *}$ & $.38^{*}$ & $.44^{* *}$ & $.38^{*}$ & $.66^{\star *}$ & $.42^{*}$ & $.48^{* *}$ & $.50^{* *}$ & - & \\
\hline $\begin{array}{l}\text { 13. Job } \\
\text { satisfaction }\end{array}$ & $.39^{*}$ & $.64^{* *}$ & $.47^{*}$ & $.55^{* *}$ & $.49^{* *}$ & $.40^{*}$ & $.64^{* *}$ & $.42^{*}$ & $.44^{*}$ & $.57^{* *}$ & $.45^{*}$ & $.43^{*}$ & - \\
\hline
\end{tabular}

Table A2: Correlations between perceived job attributes and job satisfaction

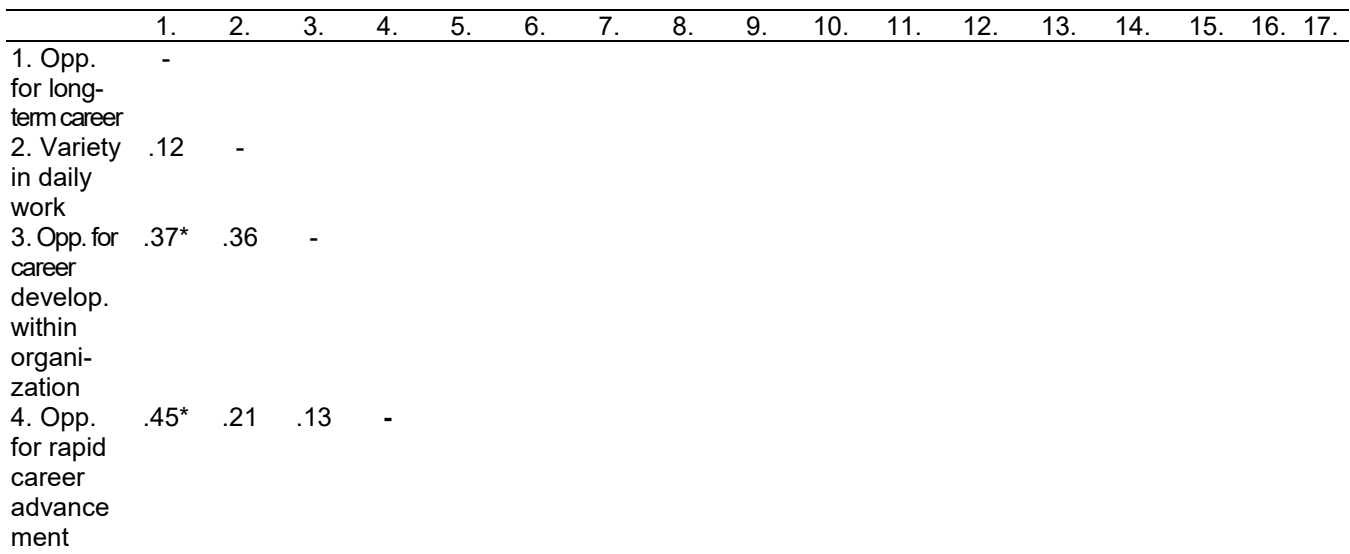




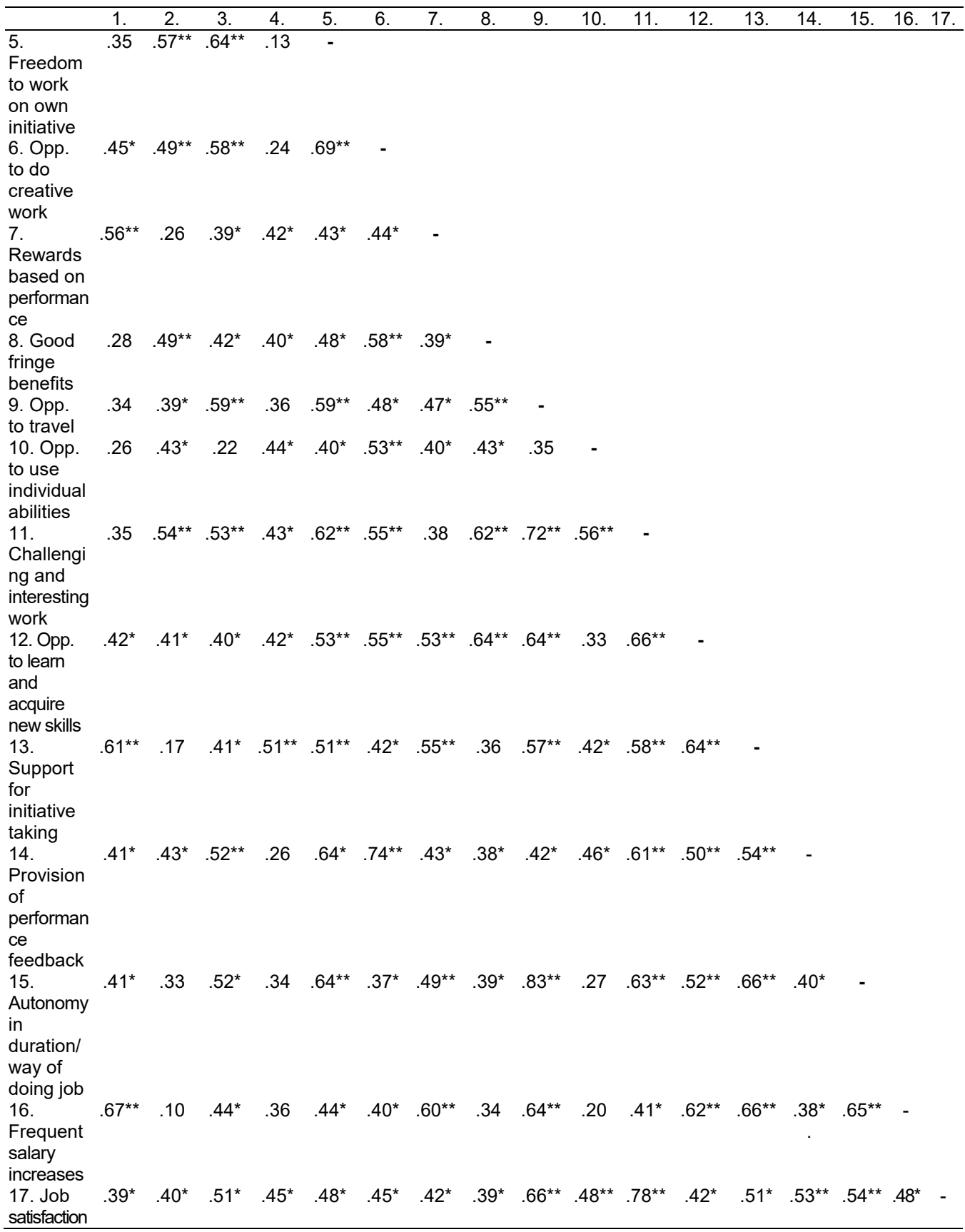

Note. ${ }^{*},{ }^{* *}$ Correlations are significant at the .05 level and .01 level, respectively (two-sided). Due to space limit, only perceived job attributes that correlated significantly with job satisfaction are reported here. Opp. = opportunity; develop. $=$ development; resp. $=$ responsibility 


\section{References}

Acikgoz Y. (2019) Employee recruitment and job search: Towards a multi-level integration, Human Resource Management Review, 29 (1), 1-13

Baker S. H., Hansen R. A. (1975) Job design and worker satisfaction: A challenge to assumptions, Journal of Occupational Psychology, 48 (2), 79-91

Barrett G. V. (1978) Task design, individual attributes, work satisfaction, and productivity. In: Negandhi A. R., Wilpert B. (eds). Work organization research: European and American perspectives. Kent, $\mathrm{OH}$ : Kent State University Press, 261-278

Behling O., Labovitz G., Gainer M. (1968) College recruiting-theoretical base, Personnel Journal, 47 (1), 13-19

Boswell W. R., Boudreau J. W., Tichy J. (2005) The relationship between employee job change and job satisfaction: the honeymoon-hangover effect, Journal of Applied Psychology, 90 (5), 882-892

Boswell W. R., Roehling M. V., LePine M. A., Moynihan L. M. (2003) Individual job-choice decisions and the impact of job attributes and recruitment practices: $A$ longitudinal field study, Human Resource Management, 42 (1), 23-37

Boswell W. R., Shipp A. J., Payne S. C., Culbertson S. S. (2009) Changes in newcomer job satisfaction over time: Examining the pattern of honeymoons and hangovers, Journal of Applied Psychology, 94 (4), 844-858

Carless S. A., Imber A. (2007) Job and organizational characteristics: A construct evaluation of applicant perceptions, Educational and Psychological Measurement, 67 (2), 328-341

Casper W. J., Buffardi L. C. (2004) Work-life benefits and job pursuit intentions: The role of anticipated organizational support, Journal of Vocational Behavior, 65 (3), 391-410

Chapman D. S., Uggerslev K. L., Carroll S. A., Piasentin K. A., Jones D. A. (2005) Applicant attraction to organizations and job choice: A meta-analytic review of the correlates of recruiting outcomes, Journal of Applied Psychology, 90 (5), 928-944

Chen, L. H. (2008) Job satisfaction among information system (IS) personnel, Computers in Human Behavior, 24 (1), 105-118

Chen G., Ployhart R. E., Thomas H. C., Anderson N., Bliese P. D. (2011) The power of momentum: A new model of dynamic relationships between job satisfaction change and turnover intentions, Academy of Management Journal, 54 (1), 159-181

Cohrs J. C., Abele A. E., Dette D. E. (2006) Integrating situational and dispositional determinants of job satisfaction: Findings from three samples of professionals, The Journal of Psychology, 140 (4), 363-395

Dormann C., Zapf D. (2001) Job satisfaction: A meta-analysis of stabilities, Journal of Organizational Behavior: The International Journal of Industrial, Occupational and Organizational Psychology and Behavior, 22 (5), 483-504

Ehrhart K. H., Ziegert J. C. (2005) Why are individuals attracted to organizations?, Journal of Management, 31 (6), 901-919 
Fried Y., Ferris G. R. (1987) The validity of the job characteristics model: A review and meta-analysis, Personnel Psychology, 40 (2), 287-322

Griffeth R. W., Hom P. W., Gaertner S. (2000) A meta-analysis of antecedents and correlates of employee turnover: Update, moderator tests, and research implications for the next millennium, Journal of Management, 26 (3), 463-488

Hackman J. R., Oldham G. R. (1975) Development of the job diagnostic survey, Journal of Applied Psychology, 60 (2), 159 -170

Hackman J. R., Oldham G. R. (1976) Motivation through the design of work: Test of a theory, Organizational Behavior and Human Performance, 16 (2), 250-279

Harold C. M., Ployhart R. E. (2008) What do applicants want? Examining changes in attribute judgments over time, Journal of Occupational and Organizational Psychology, 81 (2), 191-218

Harris M. M., Fink L. S. (1987) A field study of applicant reactions to employment opportunities: Does the recruiter make a difference?, Personnel Psychology, 40 (4), 765-784

Herzberg F.I. (1966) Work and the nature of man. Cleveland, World publishing company

Humphrey S. E., Nahrgang J. D., Morgeson F. P. (2007) Integrating motivational, social, and contextual work design features: A meta-analytic summary and theoretical extension of the work design literature, Journal of Applied Psychology, 92 (5), 1332-1356

Humphrys P. (1981) The effect of importance upon the relation between perceived job attributes, desired job attributes and job satisfaction, Australian Journal of Psychology, 33 (2), 121-133

Joseph D., Ng K. Y., Koh C., Ang S. (2007) Turnover of information technology professionals: A narrative review, meta-analytic structural equation modeling, and model development, MIS Quarterly, 31 (3), 547-577

Judge T. A., Parker S. K., Colbert A. E., Heller D., llies R. (2002) Job satisfaction: A cross-cultural review. In: Anderson N., Ones D. S., Sinangil H. K., Viswesvaran C. (eds). Handbook of Industrial, Work and Organizational Psychology, Vol. 2. Organizational Psychology. Sage Publications, Inc., 25-52

Jurgensen C. E. (1978) Job preferences (What makes a job good or bad?), Journal of Applied Psychology, 63 (3), 267-276

Keller A. C., Semmer N. K. (2013) Changes in situational and dispositional factors as predictors of job satisfaction, Journal of Vocational Behavior, 83 (1), 88-98

Konrad A. M., Corrigall E., Lieb P., Ritchie Jr J. E. (2000) Sex differences in job attribute preferences among managers and business students, Group \& Organization Management, 25 (2), 108-131

Kuhn K., Joshi K. D. (2009) The reported and revealed importance of job attributes to aspiring information technology: a policy-capturing study of gender differences, ACM SIGMIS Database: the DATABASE for Advances in Information Systems, 40 (3), 40-60

Locke E. A. (1969). What is job satisfaction?, Organizational Behavior and Human Performance, 4 (4), 309-336

Loher B. T., Noe R. A., Moeller N. L., Fitzgerald M. P. (1985) A meta-analysis of the relation of job characteristics to job satisfaction, Journal of Applied Psychology, 70 (2), 280- 289 
Mihalca L., Mengelkamp C., Brendea G., Metz D. (in press) Job attribute preferences of incoming university students and newly-hired employees in the context of the Romanian labour market

Niederman F., Sumner M. (2004) Effects of tasks, salaries, and shocks on job satisfaction among MIS professionals, Information Resources Management Journal (IRMJ), 17 (4), 49-72

O'Brien G. E., Dowling P. (1980) The effects of congruency between perceived and desired job attributes upon job satisfaction, Journal of Occupational Psychology, 53 (2), 121-130

Posner B. Z. (1981) Comparing recruiter, student, and faculty perceptions of important applicant and job characteristics, Personnel Psychology, 34 (2), 329-339

Powell G. N. (1984) Effects of job attributes and recruiting practices on applicant decisions: A comparison, Personnel Psychology, 37 (4), 721-732

Powell G. N. (1991) Applicant reactions to the initial employment interview: Exploring theoretical and methodological issues, Personnel Psychology, 44 (1), 67-83

Sachau D. A. (2007) Resurrecting the motivation-hygiene theory: Herzberg and the positive psychology movement, Human Resource Development Review, 6 (4), 377-393

Schneider S. C. (1987) Information overload: Causes and consequences, Human Systems Management, 7 (2), 143-153

Taylor J., Westover J. H. (2011) Job satisfaction in the public service: The effects of public service motivation, workplace attributes and work relations, Public Management Review, 13 (5), 731-751

Tett R. P., Meyer J. P. (1993) Job satisfaction, organizational commitment, turnover intention, and turnover: path analyses based on meta-analytic findings, Personnel Psychology, 46 (2), 259-293

Trauth E. M., Quesenberry J. L., Huang H. (2009) Retaining women in the US IT workforce: theorizing the influence of organizational factors, European Journal of Information Systems, 18 (5), 476-497

Turban D. B., Forret M. L., Hendrickson C. L. (1998) Applicant attraction to firms: Influences of organization reputation, job and organizational attributes, and recruiter behaviors, Journal of Vocational Behavior, 52 (1), 24-44

Twenge J. M., Kasser T. (2013) Generational changes in materialism and work centrality, 1976-2007: Associations with temporal changes in societal insecurity and materialistic role modelling, Personality and Social Psychology Bulletin, 39 (7), 883-897

Uggerslev K. L., Fassina N. E., Kraichy D. (2012) Recruiting through the stages: A meta-analytic test of predictors of applicant attraction at different stages of the recruiting process, Personnel Psychology, 65 (3), 597-660

Wanous J. P., Reichers A. E., Hudy M. J. (1997) Overall job satisfaction: how good are single-item measures?, Journal of Applied Psychology, 82 (2), 247-252

Warr P., Inceoglu I. (2012) Job engagement, job satisfaction, and contrasting associations with person-job fit, Journal of Occupational Health Psychology, 17 (2), 129-138 